\section{ANALYSIS OF THE TOPOLOGY OF „SHORE TO SHIP" SYSTEMS - POWER ELECTRONIC CONNECTION OF SHIPS WITH LAND}

DOI 10.2478/ntpe-2018-0040

\author{
Dr inż. Dariusz Tarnapowicz \\ Maritime University of Szczecin, Poland \\ Prof. Sergei German-Galkin \\ ITMO University Saint-Petersburg, Russia
}

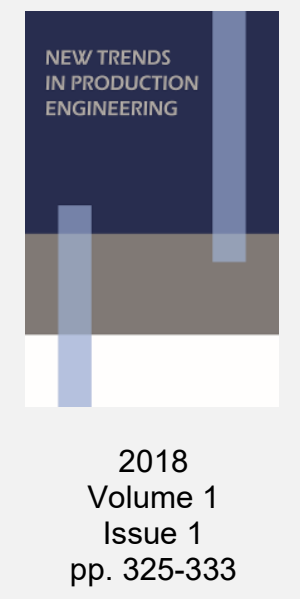

\begin{abstract}
The possibility of building efficient and universal systems for the use of electricity land network by ships berthed in the port appeared along with the development of power electronic technologies. The need to connect ships to the land network is primarily related to ecological reasons. The choice of the appropriate topology by the investor (usually port authorities) is mainly connected with ensuring high quality of electricity provided to the ship and local conditions. The article reviews topologies of power electronic system (possible to use) for connection of ships with the land network - their disadvantages and advantages.
\end{abstract}

Keywords: "Shore To Ship" system, frequency inverter, high voltage power supply

\title{
INTRODUCTION
}

Please note that the full paper should not exceed Among many means of transport (car, maritime, railway, air), seagoing ships are the main source of air pollution (Borkowski et all., 2012), (Borkowski et all., 2013). When a ship is stationed at a port that is often located close to human settlements, the limitation of air pollutant emission by vessels becomes a priority. International maritime organizations (among other things IMO - International Maritime Organization) are looking for methods to solve this problem.

The IMO has introduced rigorous principles for reducing the emission of sulfur oxide (SOx) by ships in selected sea areas (SECA-Sulphur Emission Control Area) and less rigorous on the remaining water regions. Similar regulations have been implemented for the limitation of NOx emission (nitrogen oxides). SOx limitation is usually conducted by the use of low sulfur fuels. The use of such fuels for marine generating sets limits the emission of SOx in the port, but it significantly increases the price of electricity generation. The use of various new technologies on ships (for example: Exhaust Gas Recirculation, Scrubbing) limiting the emission of air pollutions are not fully effective. Individual solutions only reduce the emission of selected components of air pollution (Borkowski and Tarnapowicz, 2014).

One of the most effective ways to reduce the negative impact of ships mooring in ports on the environment the supply of electricity on ships from local power stations. This will enable to switch off ship's generating sets and eliminate emission of combustion gases during the stay of unit in the port, while simultaneous reduction of noise and vibrations. The use of power electronic connection between the ship and the land network (Shore to Ship - STS) not only provides ecological benefits, but it also gives economic advantages. The cost of generating electricity with the use of low sulfur fuels on the ship is several times greater than the cost of energy obtained from the land network (Tarnapowicz and German-Galkin, 2016). The necessary condition for the connection of marine power electronic network with the land network is the compatibility of voltage parameters and the power level needed to ensure the safe exploitation of the ship in the port. A voltage parameter, which should be based on modern power electronic technologies, is the frequency. In marine electricity systems, frequencies of $50 \mathrm{~Hz}$ or $60 \mathrm{~Hz}$ are sued - depending on the type of vessel and regions, where the ship floats (Borkowski and 
Tarnapowicz, 2014). In the electricity land grid, the same frequencies are used in accordance with the regions of the world. The second essential parameter is to achieve the same voltage levels for both electricity systems. This is realized by the use of conditioning transformers (matching). A commonly used solution is the installation of matching transformers on the ship's side.

The power of the STS system depends on the analysis of the power demand of ships mooring in a specific port (Matuszak et all., 2015).

The universal STS system has been approved by the European Union in 2006. It allows the connection to the land network of ships with different rating parameters of ship's grid (EU Commission recommendation, 2006). Figure 1 presents the basic elements of such a system.

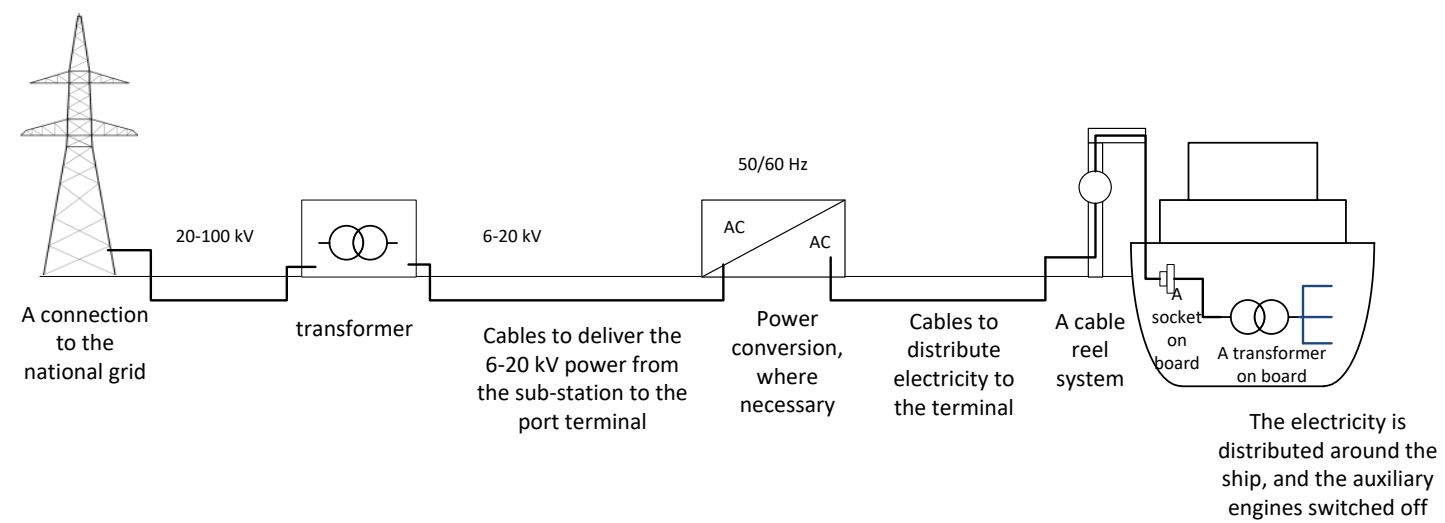

Fig. 1. The scheme of ship electric supply system configuration (STS) in the port according to EU regulations.

Source: own work based on (EU Commission recommendation, 2006)

The main elements of the system determining all costs are frequency converters. In STS systems, there were attempts to apply other solutions, e.g. the use of LNG-Generator sets (Tarnapowicz and German-Galkin, 2016). However, the most effective solutions remained the semiconductor frequency converters. IGBT transistors are elements of inverters. They enable to get high quality of electricity. The use of these semiconductor components allows the implementation of converters with the power up to 3 MVA. Higher power ratings can be obtained by the use of IGCT thyristors. This solution deteriorates the quality of obtained electricity because of the tens of times lower connecting frequency of these semiconductors. In high power converters, the best solutions are multilevel inverters based on IGBT transistors (Blecharz and Krzemiński, 2014).

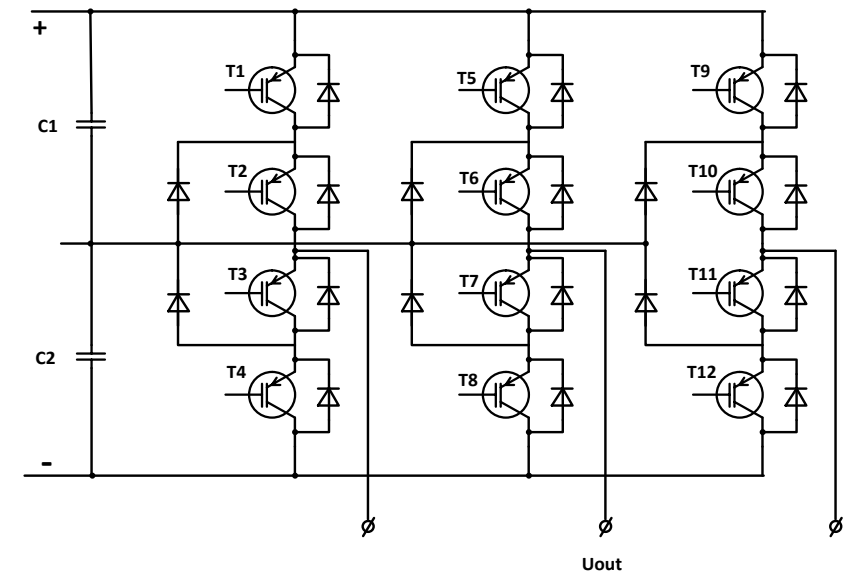

Fig. 2. 5-level inverter.

Figure 2 shows an exemplary topology of a 5-level inverter. In relation to a 3-level inverter (classical inverter), the voltage class of transistors has been increased, while simultaneous reduction of the total harmonic distortion (THD). Figure 3 presents the results of simulation 
researches for a 5-level inverter in relation to a 3-level inverter (for one phase). There is a noticeable increase in the quality of voltages generated by a 5 -level inverter (3-level THD = $4.21 \%$, 5-level THD $=2.35 \%$ ).

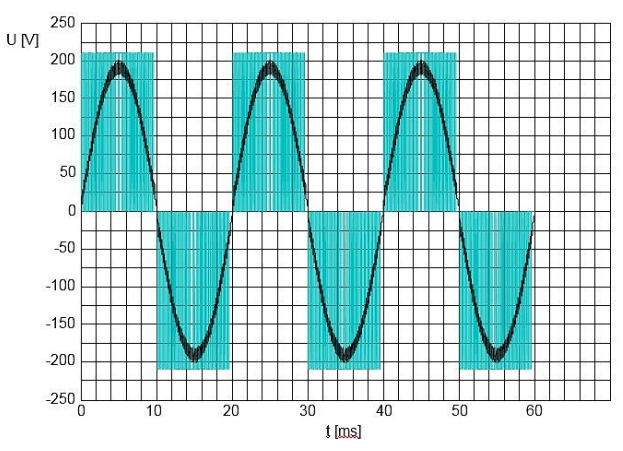

$\mathrm{THD}=4.21 \%$

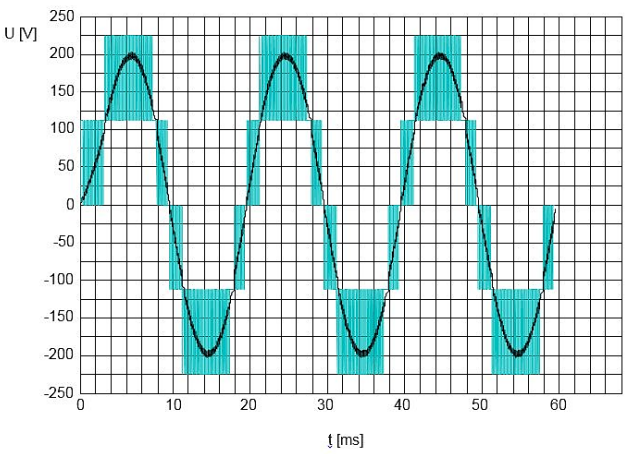

$\mathrm{THD}=\mathbf{2 . 3 5 \%}$

Fig. 3. Courses of output voltages and receiver network of 3-level and 5-level inverter - simulation researches.

The second important element of the STS system is conditioning transformers. Transformer construction technology is widely known, and producers offer a full assortment. Dimensional limitations are an important determinant deciding on thy type of applied transformers. Distribution stations with installed transformers are located in port areas - often directly on quays.

The last important element of the system is connection installations. The connector must be secure and it resistant to frequent switching on and off. Connection can be carried out manually or automatically.

\section{METHODOLOGY OF RESEARCH}

Comparative analysis of the topology of the system's STS

In order to increase the universality of the system, and (above all) to maintain operational safety, global provisions for the design of STS system have been implemented. Currently, there are two standards (Tarnapowicz and German-Galkin, 2018). For ship power plants with power above 1 MW (the majority of ships), medium voltage (MW in the global nomenclature HV - High Voltage) is used in accordance with IEC/ISO/IEEE 80005-1 standard (IEC/ISO/IEEE, 2012) and for ships with a power of marine power plants up to $1 \mathrm{MW}$, the law voltage (LV) is used in accordance with IEC/ISO/IEEE 80005-3 standard (IEC/ISO/IEEE, 2014).

The connection of the marine electricity grid with the mainland network has been known for a long time. A separate area for connecting to the land was located in the ship's GTR (MSB Main Switch Board). This solution had disadvantages:

- Lack of versatility - the ship network could be connected to the land network only with the same voltage parameters (this state was rate)

- Connection with power interruption - connection to the land network only via BLACKOUT on the ship

- Limitation of power that is used on the ship

Currently designed STS systems are fully universal and uninterruptible. The further part of this article presents an comparative analysis of the possible topologies of STS systems for power in ship's power plants above $1 \mathrm{MW}$.

\section{RESULTS}

\section{Topology of STS system - Variant I}

Figure 4 shows a topology with one high-power converter that can power several quays at the same time. 


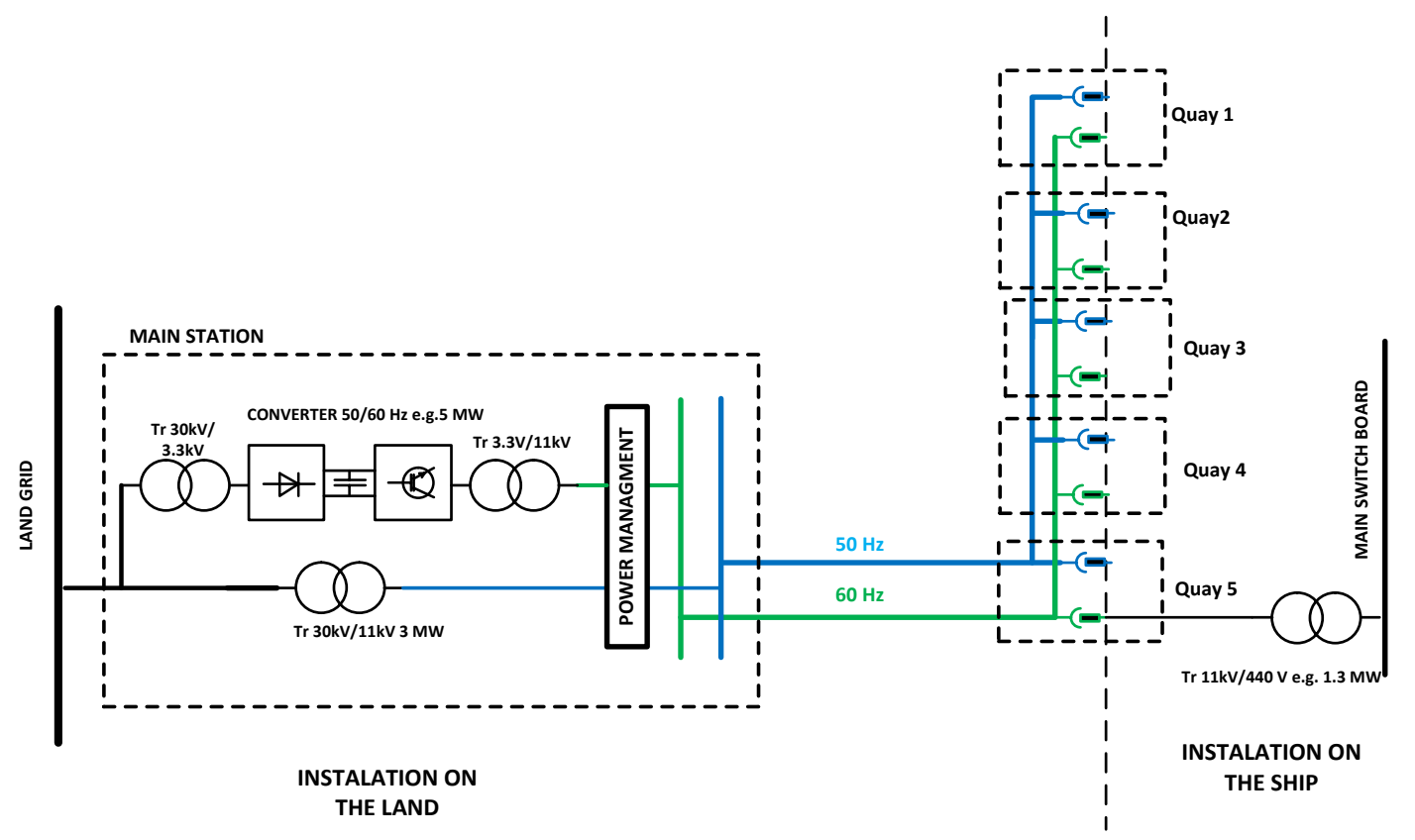

Fig. 4. Variant I - high power frequency converter.

Two AC BUS - $50 \mathrm{~Hz}$ or $60 \mathrm{~Hz}$

Essential elements of the STS system are located in the main station, which due to its large dimensions must be located away from quay. Frequency inverter supplies matching transformers, which are located in the main distribution station. The power of the frequency inverter and matching transformers, depending on the specific conditions of the port, usually ranges from a few to $10 \mathrm{MW}$. Similar to the situation presented in Figure 4, this solution was realized in one of the ports in Sweden. During the operation of the STS system, there were occasional failures caused by one of the connected vessels. These failures resulted in the deactivation of the entire system and BLACKOUT in other ships. The provision of high-quality electricity from the STS system, and thus also uninterrupted operation of the system is fundamental for safety reasons in ships. Frequency converters of such high power require special service (the possibility of no service in a certain country).

Because of technological limitations, the frequency inverter is usually created on the basis of IGCT thyristors - i.e. valves with less switching frequency. This has a negative impact on the quality of generated voltage flows.

\section{Topology of STS system - Variant II}

The topology of variant II is presented in Figure 5. A few frequency inverters (Figure 5 - three inverters) of lower power (usually around $1 \mathrm{MW}$ ) were applied. Frequency converters and matching transformers are located in the main distribution station. In the first and second topology, connecting cables are distributed independently.

The power of converters is about $1 \mathrm{MW}$ (each). Variant II also enables the use of inverters in parallel operation (Power Management) when powering a ship with higher power requirements. The main advantage of the variant II is the ability to ensure an independent operation of systems for frequency inverters what significantly increases the reliability of the STS system. Problems occurring in variant I of the STS system are not present.

The disadvantage of this solution is the larger surface of the main station necessary for installation of more converters and transformers than in variant $I$.

There is a possibility of modular solution for variant II with the use of containers that are equipped with full paths of transformation (converter and matching transformers) (Figure 6).

In the future, this will enable an easy expansion of the STS system with additional modules (converters). Modular concept enables the construction of converters of any power ranging from several hundred kVA to over 10 MVA. Modules can be mounted in cabinets or in the form of a so-called Rack. The most interesting and possible for the realization solution for STS systems 
was presented by ABB. Thanks to the suggested modular construction located in containers, it is possible to obtain the uninterrupted operation even with damaged (automatically disconnected) modules with slightly reduced parameters - so-called advanced redundancy.

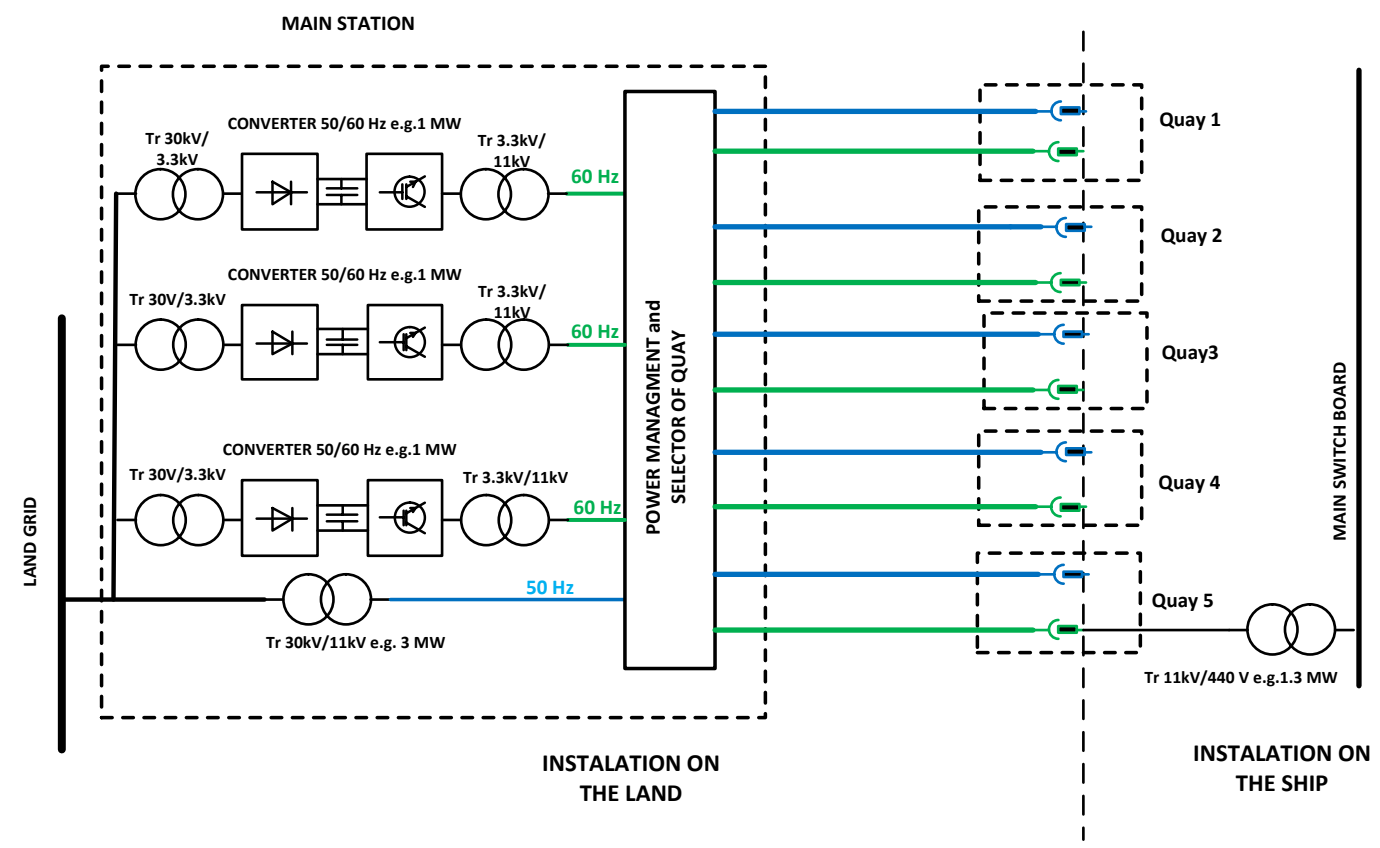

Fig. 5. Variant II - a few converters of lower power. Two AC BUS - $50 \mathrm{~Hz}$ or $60 \mathrm{~Hz}$

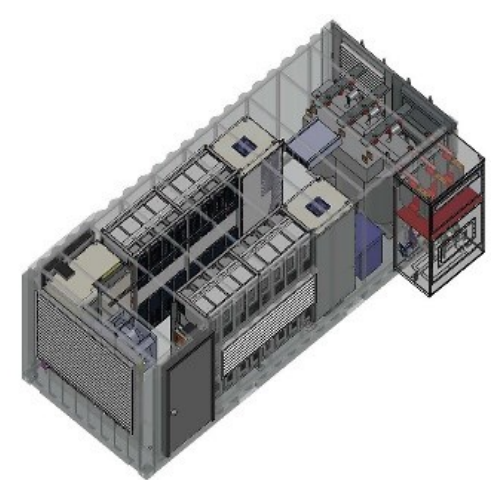

Fig. 6. Container station - modules of converters in the Rack form. Source: Budzisz and Warzyński, 2012.

Figure 7 shows a comparison of a classical single converter with modules based on advanced redundancy located in containers (Budzisz and Warzyński, 2012).

Advanced redundancy allows:

- Continuous operation of the system with reduced power in case of failure of a single module

- The ability to build a system with a number of $n+1$ modules, resulting in further increase in the reliability and availability of power

- Flexible planning of repair or replacement of a single module during operation

Moreover, the overload is possible: $120 \% 10 \mathrm{~min} ; 150 \% 30 \mathrm{sec}$.; $175 \% 2 \mathrm{sec}$. Higher overloads can be achieved by adding more modules.

A great advantage of variant II is possibility of the synchronization of the ship power grid with the land network using control of single frequency converters, which is not possible in variant I (Tarnapowicz, 2013). In the variant I it is a troublesome to synchronize with the use of marine auxiliary engines, which fuel dose (rotations) is changed at a full load. 


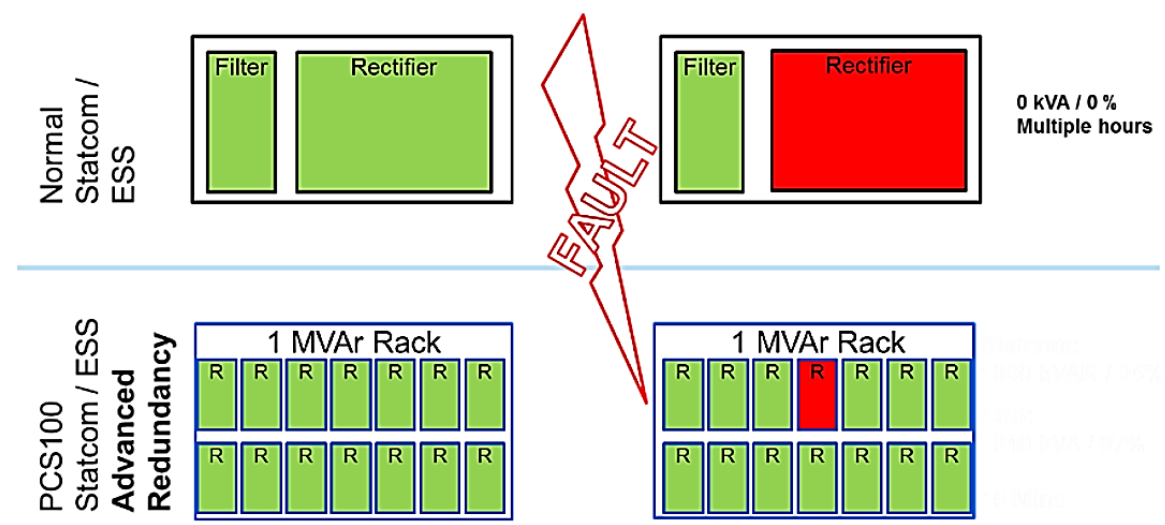

Fig. 7. Multi-level redundancy designed by $A B B$.

Source: Budzisz and Warzyński, 2012.

In variant II, it is possible to save the number of connecting cable by the installation of the frequency selector (Figure 8).

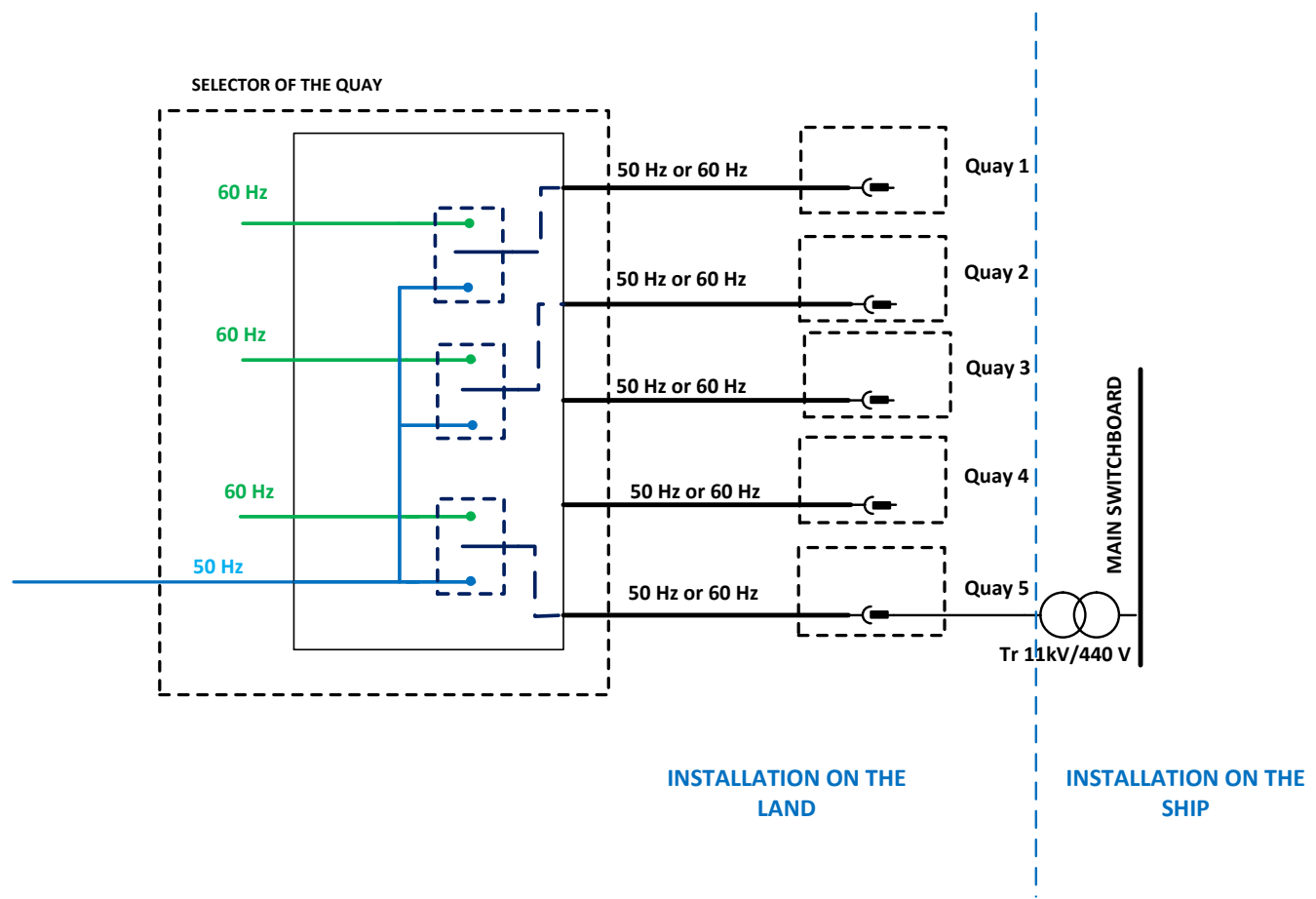

Fig. 8. Frequency selector.

\section{Topology of STS system - Variant III}

The main advantage of the topology HVDC presented in Figure 6 is the ability to transfer energy between systems with different frequencies. In the main switchboard, AC voltage is converted (via rectifier) to DC voltage and in this changed form, it is transferred to local inverter, where it is changed again to AC voltage.

Advantages from the transfer of DC power are well known:

- Transfer losses are reduced by 33 percent

- Transfer power is independent of distance

- Transmission line does not require reactive power compensation

- HVDC systems can combine two asynchronously operating power systems

- HVDC systems enable quick control of volumes and directions of power flow

One of the disadvantages of the topology shown in Figure 9 is a decrease in the reliability of the systems by suing one AC/DC converter in the main distribution station. The failure of this inverter disables the entire STS system. 


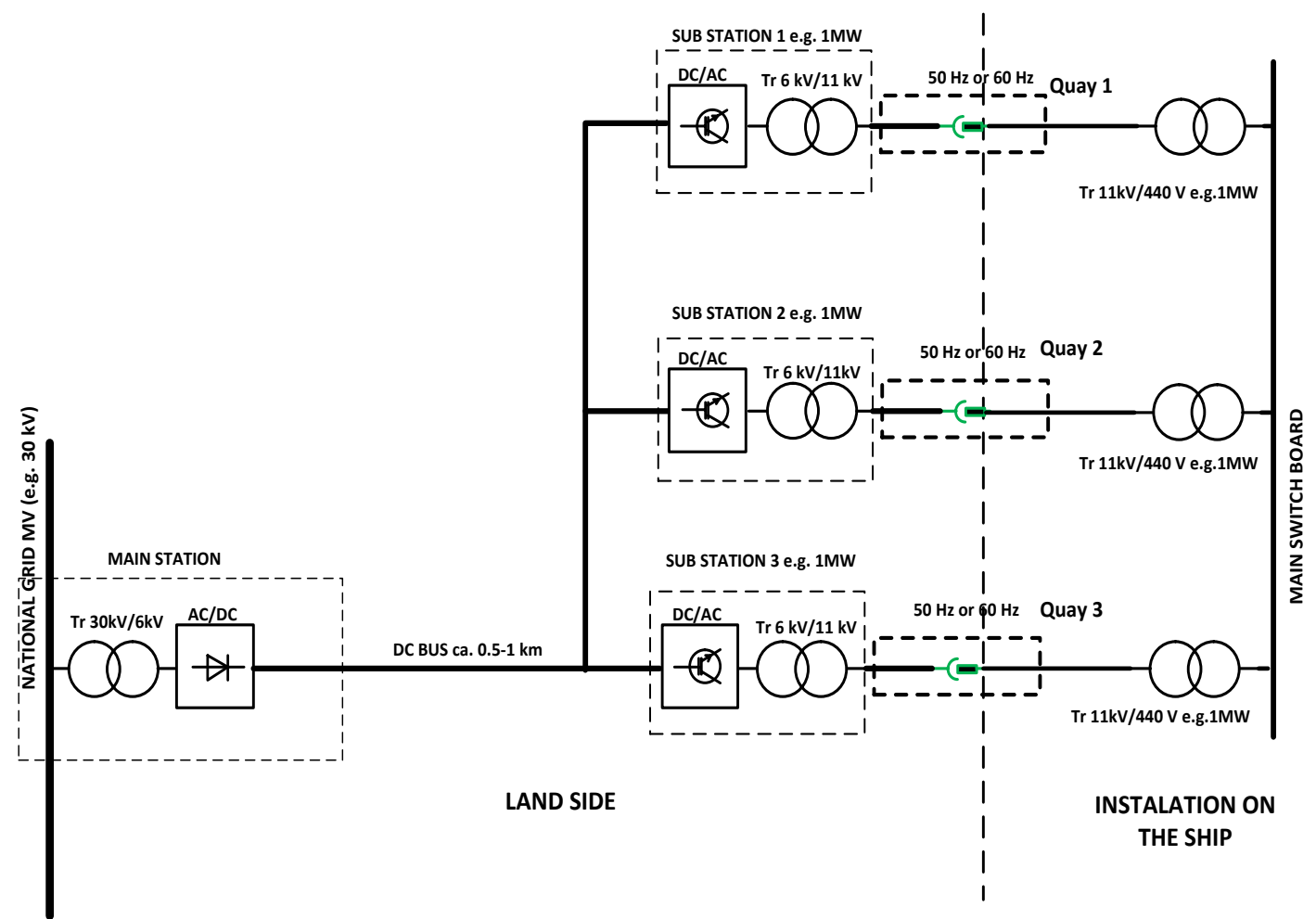

Fig. 9. Variant III - HV power supply. (HVDC - Transmission)

This topology can be modernized by using several AC/DC converters with smaller power operating independently on each quay. In first and second variant, conversion devices on quay are not planned. This is important for ports, in which STS systems are projected. Inverters with large dimensions would interfere with the infrastructure of wharves - causing difficulties in the work of ports. The solution for this problem can be mobile platforms, on which inverters and matching transformers are installed (Strzelecki et all., 2015) (Figure 10).

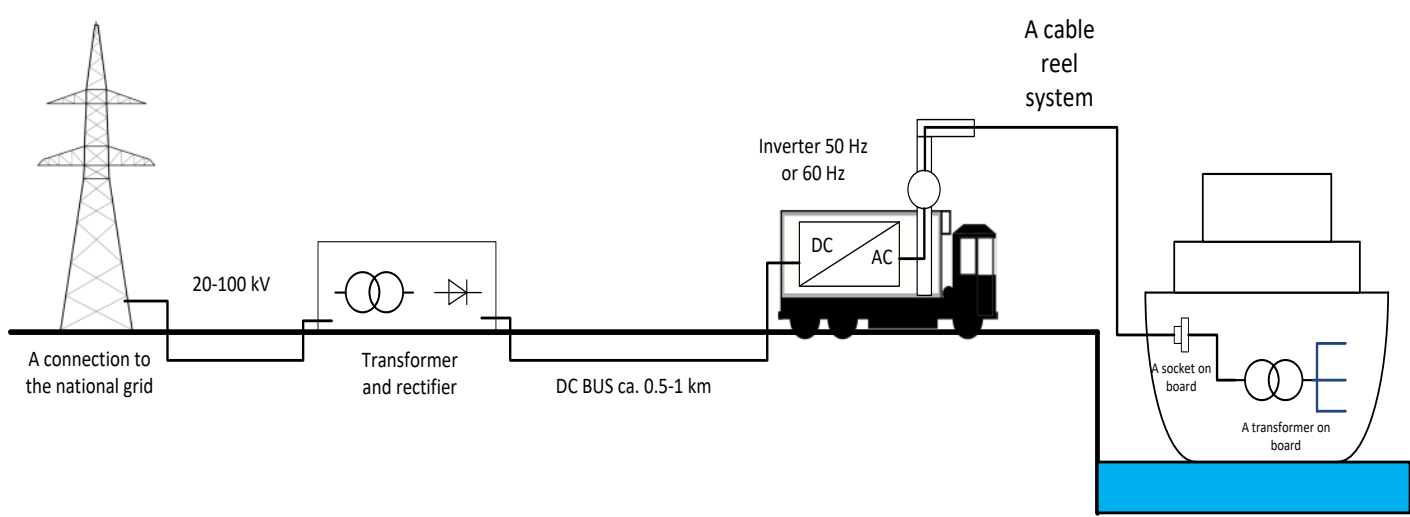

Fig. 10. Variant III (HVDC - Transmission) with the use of mobile platforms.

\section{DISCUSSION}

Selection of the right topology depends on the nature of a port, variety of ships in the port (power, voltage parameters of the ship's power plants), size of harbor wharves and their nature. The Table presents a comparison of the described topologies of the STS system. 
Comparison of the described topologies of the STS system

\begin{tabular}{|c|c|c|}
\hline Topology & Advantages & Disadvantages \\
\hline Variant I & $\begin{array}{l}\text { - Small area of the main station } \\
\text { and long distance from quays } \\
\text { - Cost of installation is slightly } \\
\text { lower than cost of other variants }\end{array}$ & $\begin{array}{l}\text { - The most fault-prone system } \\
\text { (failure of the inverter disables } \\
\text { all terminals) } \\
\text { - Limited availability of highly } \\
\text { specialized service for high } \\
\text { power converters } \\
\text { - Low quality of electricity (high } \\
\text { THD) - the need to use } \\
\text { harmonic filters } \\
\text { - no possibility of synchronizing } \\
\text { systems using inverter control }\end{array}$ \\
\hline Variant II & $\begin{array}{l}\text { - Failure of one of the inverters } \\
\text { disconnects only one terminal; } \\
\text { other terminals work without any } \\
\text { problems } \\
\text { - Possibility to increase the } \\
\text { reliability through the use of } \\
\text { multi-level redundancy } \\
\text { - Possibility of parallel operation } \\
\text { of modules in order to ensure } \\
\text { power for ships with high power } \\
\text { requirements } \\
\text { - Ease of access to service } \\
\text { - High quality of generated } \\
\text { voltages from inverters based } \\
\text { on IGBT transistors } \\
\text { - Possibility of placing } \\
\text { autonomous installations in } \\
\text { containers and thus increasing } \\
\text { the possibilities for expansion of } \\
\text { the STS system } \\
\text { - possibility of synchronizing } \\
\text { systems using inverter control }\end{array}$ & $\begin{array}{l}\text { - Cost of installation is slightly } \\
\text { higher than in variant I }\end{array}$ \\
\hline Variant III & $\begin{array}{l}\text { - Surface of the main station is } \\
\text { the smallest of all variants } \\
\text { - High efficiency due to smaller } \\
\text { losses in rail and DC cable lines } \\
\text { - Modularity for easy expansion }\end{array}$ & $\begin{array}{l}\text { - Placement of inverters in } \\
\text { quays interferes with the port } \\
\text { infrastructure } \\
\text { - Failure of } A C / D C \text { converter in } \\
\text { the main station prevents the } \\
\text { operation of terminals }\end{array}$ \\
\hline
\end{tabular}

\section{CONCLUSION}

The presented analysis of topologies for STS system leads to the conclusion that the most effective solution, and above all the most reliable solution, is variant II. Variant III can be used in the case of significant distances between the main station and quays, as well as the possibility of designing quays in order to ensure that the inverters do not affect the transport in quays. Variant I is unfavorable due to the unreliability of the system.

\section{ACKNOWLEDGEMENTS}

This research outcome has been achieved under the research project: Nowoczesne technologie w systemach "Shore to Ship" No 2/S/IEiAO/16 financed from a subsidy of the Ministry of Science and Higher Education for statutory activities

\section{REFERENCES}

Borkowski, T., Tarnapowicz, D. and Nicewicz, G. (2012). Ships mooring in the port as a threat to our natural environment. Management Systems in Production Engineering, 2(6), pp. 2227

Borkowski, T., Tarnapowicz, D. and Nicewicz, G. (2013). The methodology used in defining air pollution from ships mooring in ports. Scientific Journals of the Maritime University of Szczecin, 36(2), pp. 17-22

Borkowski, T. and Tarnapowicz, D. (2014). Shore to Ship System: Alternative Power Supply of Ships in Ports. Szczecin, Poland: Scientific Publishing House of the Maritime University. 
Matuszak, Z., Nicewicz, G., Stoklosa, J., Kaplon, A. and Jurecki, R. (2015). Results of load's observation for selected marine electric power plants systems in floating objects. In: Selected Problems of Electrical Engineering and Electronics WZEE. Kielce, Poland

Publisher IEEE, 345 E 47TH ST, NEW YORK, NY 10017 USA, pp. 1-6

Tarnapowicz, D. and German-Galkin, S. (2016). The use of generating sets with LNG gas engines in "Shore to Ship" systems. Management Systems in Production Engineering, 3(23), pp. 172-177

EU Commission recommendation, (2006). On the promotion of shore-side electricity for use by ships at berth in Community ports. EU law and publications.

Blecharz, K. and Krzemiński Z. (2014). Nowoczesne układy przekształtników wielopoziomowych do zasilania statków z lądu. [pdf] Gdynia. Available at https://www.port.gdynia.pl/files/dla_najemcy/dostawy_mediow/i_seminarium.pdf/ [Accessed 20 Apr. 2017].

Tarnapowicz, D. and German-Galkin, S. (2018). International Standardization in the Design of "Shore to Ship" - Power Supply Systems of Ships in Port. Management Systems in Production Engineering, 26(1), pp. 9-13

IEC/ISO/IEEE, (2012). 80005-1: International Standard Utility connections in port - Part 1: High Voltage Shore Connection (HVSC) Systems - General requirements Edition 1.0. ISO Publications.

IEC/ISO/IEEE, (2014). 80005-3 Utility connections in port - Part 3: Low Voltage Shore Connection (LVSC) Systems - General requirements. Edition 1.0. ISO Publications.

Budzisz, M. and Warzyński, P. (2012) Urządzenia optymalizujące parametry sieci. [ppt] ABB Group Power Electronics. Available at: http://www02.abb.com/global/plabb/plabb045.nsf/0/82543013f4215130c12579fe0033f556 /\$file/1.1+pcs100_statcom-ess_product_appl_pl.ppt [Accessed 20 Apr. 2017].

Tarnapowicz, D. (2013). Synchronization of national grid network with the electricity ships network in the "shore to ship" system. Management Systems in Production Engineering, 3(11), pp. 9-13

Strzelecki, N., Mysiak, P. and Sak, T. (2015). Solutions of Inverter Systems In Shore-to-Ship Power Supply Systems. In: International Conference on Compatibility and Power Electronics. Costa da Caparica, Portugal pp. 454-461. Available at: http://ieeexplore.ieee.org/stamp/stamp.jsp?tp=\&arnumber=7231118/ [Accessed 11 Jan. 2017]. 